https://doi.org/10.18485/kud_kiaz.2019.ch45

Фируза Хаятова

АУЯ- преподаватель

Кафедры Регионоведение

\title{
АЗЕРБАЙДЖАН ПЕРИОД ПЕРВОЙ БРИТАНСКОЙ ВОЕННОЙ ОККУПАЦИИ
}

\section{SUMMARY}

The policies of Great Britain in Azerbaijan during the First World War were reflected in the works of major specialists dedicated to the history of Azerbaijan. Britain was interested in arming the Christian population of the Caucasus and a plan was adopted to create a solid belt of land under British control, as well as to establish British control over the Caspian Sea and the South Caucasus with the purpose of mastering oil Baku. But the British expansion in Baku ended in failure. The British command could not arrange the export of Baku oil to the front and was completely disappointed in its allies, from whom there was no real help.

Key words: Great Britain, First World War, Caucasus.

Тема политики Великобритании в Азербайджане в годы Первой мировой войны нашла свое объективное отражение в работах азербайджанских историков, а также в трудах других крупных специалистов посвященных истории Азербайджана в политике иностранных государств.

В годы Первой мировой войны в Британии преимущество получил план создания сплошного пояса земель под британским контролем, а также установление британского контроля над Каспием и Южным Кавказом с целью овладения нефтяным Баку. Известная фраза Керзона в 
конце 1918 года «Союзники пришли к победе на волнах нефти» объясняла устремления британских властей. По мнению Бальфура, нужно было захватить Батум, Баку, а также пути транспортировки нефти. Его заместитель Сесиль также подчеркивал целесообразность захвата нефтяного Баку. Кроме того, нельзя сбрасывать со счетов и то, что в годы Первой мировой войны на долю Великобритании приходилось $60 \%$ всех капиталовложений в бакинские нефтепромыслы.

Интересы Великобритании совпадали с интересами армян, которые видели в ней свою союзницу и благодетельницу. Армянские националисты и сепаратисты не оставляли свои планы и вели переговоры как с российскими, так и с европейскими властями. Великобритания стремилась во что бы то ни стало получить доступ к бакинской нефти. В тоже время Великобритания опасалась, что Баку станет выходом для германо-турецких войск в Среднюю Азию и британскую Индию.

Планы европейских держав подстегнули политические процессы, происходящие по нарастающей в России. После произошедшего России в октябре 1917 году государственного переворота, последовал тотальный развал царской армии, большевистское правительство России заявило о прекращении военных действий, выходе из Антанты и намерение заключить мир. Установленная Советское руководство приняло решение о немедленном принятии условий Германии на переговорах в Брест-Литовске. 3 марта между РСФСР и странами Четверного союза был подписан мирный договор, по условиям которого Россия уступала 750 тыс. кв. км территории.

По тайному договору между Великобританией и Францией от 23 декабря 1917 года, Великобритании отходил Северный Кавказ, Южный Кавказ, Туркестан. Стратегический планы Великобритании заключались в нейтрализации российского влияния на Кавказе в том числе в Азербайджане. Наибольшее значение правитель- 
ство Великобритании уделяло Баку и Каспию. Кабинет министров Великобритании принял решение об отправке войск в Баку и на Южный Кавказ. Был дан приказ отправить отборный сводный отряд генерала Л. Денстервиля в Баку. Отряд генерала У. Маллесона должен был следовать в Мешхед и далее в Восточный Прикаспий.

Великобритания были заинтересованы в вооружении христианского населения Кавказа в частности, армян. Эта политика вызвало недовольство в Азербайджане. Капитан Ноэль 22 января сообщил о том, что в Азербайджане отношение к англичанам изменилось к худшему. Он писал: «Когда я был здесь 6 недель назад лидеры азербайджанской общины вели себя явно дружественно к нам. Сейчас, после моего возвращения в Баку, я обнаружил, что их поведение сменилось на подозрительность и плохо скрываемую враждебность. Он объяснял это следующим: общераспространенное мнение, что англичане отдают предпочтение армянским интересам; факт того, что армяне усиливают это впечатление и свободно спекулируют им; приоритет, придаваемый формированию армянского национального полка. Мусульманские интересы слишком сильны, чтобы их можно было игнорировать. Азербайджанцы сформируют свои национальные полки.., и будет лучше, если это произойдет под нашей эгидой».

После Брест-Литовского мирного договора от 3 марта 1918 года деятельность великих держав активизировалась. В конце марта 1918 года с целью координации всей военной и политической деятельности Великобритании на Ближнем и Среднем Востоке, Кавказе и Средней Азии был создан «Восточный комитет». В его состав входили лорд Керзон, министр иностранных дел Бальфур, зам министра иностранных дел лорд Сесиль, начальник имперского генерального штаба Г.Вильсон, начальник военной разведки генерал-майор Дж.Макдонэ. Председатель «Восточного комитета» Керзон выдвинул план оккупации стратегических пунктов и коммуникаций Южного Кавка- 
за, выдвигая на первый план нефтеносный Баку. Члены комитета придавали огромное значение также железной дороге Баку-Батум и нефтепроводу.

28 мая 1918 года Национальный Совет Азербайджана подписал Декларацию о независимости Азербайджанской Республики. Великобритания была сильно обеспокоена выходом России из Антанты и изменением ее политического строя. Наступление германо-турецких войск на Кавказ весной-летом 1918 года вызвало опасение у британского кабинета.

Надо отметить, что уже в январе 1918 года ограниченная британская военная группа под командованием генерала Денстервиля («Данстерфорс») была выдвинута на южное побережье Каспия. Перед Денстервилем была поставлена задача установить контроль над западным побережьем Каспийского моря (порт Энзели) и захватить порт Баку, чтобы не допустить германо-турецкое продвижение. В Баку Мак-Донелла установил тесные связи с дашнакскими деятелями. Он организовал встречу Денстервиля с представителем Армянского Национального Совета Тер-Газаровым, который просил помощи у англичан и просил их «немедленно выступить». Армяне панически боялись приближения османской армии к Баку и рассчитывали на то, что Великобритания оккупирует Южный Кавказ.

Лидер азербайджанского национального движения М.Э.Расулзаде писал об этом так: «Большевистские и дашнакские отряды, сжатые извне турецкими и азербайджанскими национальными силами, были внутренне расшатаны и между ними начинались разногласия. Директория приглашает в Баку англичан. Приняв это приглашение, английское командование, находящееся на тот момент в Персии, высаживает в Баку войска».

Взаимная заинтересованность создавала еще одну опору английской экспансии в Баку, хотя английские дипломаты и признавали, что «армяне, как нация, трусливы и предпочитают добиваться своей цели интригами. Они в 
самом деле большие интриганы, а дашнаки были крупными специалистами по части тайных дел».

Армянские солдаты-фронтовики, скопившиеся в Баку по возвращении из Кавказского фронта, совместно с большевиками и дашнаками учинили геноцид тюрко-мусульманского населения Азербайджана. Главнокомандующий британскими войсками в Индии в своем секретном сообщении от 20 июля 1918 года подчеркивал, что армяне вредили общему делу, т.к. кичились перед азербайджанцами, что они находятся под особым покровительством англичан.». Англичане вели подготовительную работу по высадке военного десанта в Баку. По договору с генералом Денстервилем, Бичерахов в начале июля высадился в Баку и пойдя на переговоры с большевиками, был принят в состав войск Бакинской коммуны. Он сделал все возможное для приготовления контроля над нефтяными промыслами и покупки Каспийского флота». 4 августа 1918 года в Баку высадился первый британский отряд под командованием полковника Стокса, численностью в 600 человек, прибывший на военном транспорте из Энзели. 9-17 августа 1918 года в Баку высадилось три батальона, батарея полевой артиллерии и несколько броневиков англичан. Это было намного меньше того, что ожидали антиазербайджанские силы в Баку. 3 месяца шли бои между Кавказской исламской армией при поддержке турецких войск, пришедших на помощь тюрко-мусульманскому населению Азербайджана, и антиазербайджанскими силами в Баку, в основном армянского происхождения.

26 августа 1918 года началось активное наступление турецких войск под непосредственным командованием Халил-паши и прибывшим 36-м дивизионом. Денстервиль приготовился к эвакуации 1 сентября.

Решающий штурм города начался утром 15 сентября 1918 года. Вечером корабли с людьми Денстервиля на борту отчалили от берега. В последствии британский генерал вспоминал, что армянские части были полностью 
деморализованы: «Среди них царила анархия, шли бесконечные митинги, а Диктатура Центрокаспия занималась интригами», - отмечал впоследствии Денстервиль в своих мемуарах. С уходом отряда Денстервиля из города Баку завершился период первой британской военной оккупации, продолжавшийся 40 дней.

Основные причины провала британской оккупации заключались в тяжелом продовольственном положении города Баку, недостаточным финансированием и малочисленностью британских войск и недееспособностью местных союзников в лице дашнаков и правых эсеров. Однако, стоит предположить, что британское командование не могло наладить вывоз Бакинской нефти на фронт и было полностью разочаровано в своих союзниках, от которых никакой реальной помощи не было. При этом, уход британского отряда был бы временным тактическим шагом. Как известно, к осени 1918 года союзные войска разгромили германо-австрийские войска на европейском театре военных действий. А в сентябре потерпели полное поражение турецкие армии на македонском фронте и в Палестине. Союзные войска оккупировали территорию Османской империи. Уход из Баку в сентябре 1918 года не означал отказ британского правительства и командования от Каспия, а по большому счету - от Персидского залива.

15 сентября 1918 года азербайджанские войска вошли в город. Турецкие войска оставались за городом в течение трех дней. Началось налаживание мирной жизни. Возобновились попытки переговоров между тремя южнокавказскими республиками.

После поражения Германской и Османской империй на фронтах первой мировой войны, османы вынуждены были 30 октября 1918 года подписать Мудросское перемирие с представителями Великобритании, уполномоченными на это державами Антанты. 


\section{Список литературы}

Gözəlova N. Azərbaycanın türk-müsəlman əhalisinin soyqırımı Britaniya Kitabxanasının arxiv sənədlərində (1918-1920). Bakı, 2014.

Qasımlı M.C. Avropa və Amerika ölkələrinin müasir tarixi. 2 hissədə. 1 hissə (1918-1945-ci illər). Ali məktəblər üçün dərslik. Bak1, BDU nəşriyyat1, 2003, $370 \mathrm{~s}$.

Qasımov M. Xarici dövlətlər və Azərbaycan (aprel işğalından SSRİ yaradılana qədərki dövrdə diplomatik-siyasi münasibətlər). B.: Qanun, 1998, 360 s.

Азербайджан, 11 ноября (29 октября) 1918 года.

Гасанлы Дж.П. История дипломатии Азербайджанской Республики: в 3 т. Т. II : Внешняя политика Азербайджана в годы советской власти (1920-1939). М.: ФЛИНТА: Наука, 2013, 720 с.

Гасанлы Дж.П. Русская революция и Азербайджан: трудный путь к независимости (1917-1920). М: Флинта, 2011, 664 с.

Генерал-майор Денстервиль. Британский империализм в Баку и Персии. 1917-1918. (Воспоминания). Тифлис, «Советский Кавказ», 1925, с.109.

Дарабади П.Г. Центральная Евразия в «большой геополитической игре» второй половины X1X-начале XX веков. (Страницы геоистории)// Кавказ и глобализация, 2007, Том 1(3), с.136-148.

Каземзаде Фируз. Борьба за Закавказье (1917-1921). Баку: CA\&CC Press, 2010, c.140.

Парвин Дарабади. Геополитическое соперничество на Кавказе в начале XX века (геоисторический очерк)// «Кавказ и глобализация», Том 1(1). 2006.

Письмо от сэра П.Кокс в Форин Офис. 25.01.1918 г./ Азербайджанская Демократическая Республика. Архивные документы Великобритании. Баку, 2008, с.178.

Расулзаде Мамед Эмин. Азербайджанская республика// Сборник произведений и писем / Сост., предисл. и примеч. С.Исхаков. - М.: Флинта, 2010

Рональд Мак-Донелл. Указ. раб, с. 122.

Юсиф-заде С. Азербайджано-британские отношения в начале XX века. Баку, 2008

Юсифзаде С.3. Первая Азербайджанская Республика: история, события, факты англо-азербайджанских отношений. Баку, «Маариф», 1998.

Decipher from Commander-in Chief, India (July 20, 1918)// AzerbaijanDemocratic Republic. Great Britain's Archrivals Documents, p.169. 


\section{РЕЗЮМЕ}

Политики Великобритании в Азербайджане в годы Первой мировой войны нашла свое отражение в работах крупных специалистов посвященных истории Азербайджана. Великобритания были заинтересованы в вооружении христианского населения Кавказа и был принят план создания сплошного пояса земель под британским контролем, а также установление британского контроля над Каспием и Южным Кавказом с целью овладения нефтяным Баку. Но английская экспансия в Баку завершилась провалом. Британское командование не могло наладить вывоз Бакинской нефти на фронт и было полностью разочаровано в своих союзниках, от которых никакой реальной помощи не было.

Ключевые слова: Великобритания, Первая Мировая Война, Кавказ. 